\title{
Meeting John Glover
}

\author{
Kenneth A. Kiewra
}

Published online: 12 May 2009

(C) Springer Science + Business Media, LLC 2009

It was a cool spring morning in San Francisco, site of the 1986 AERA conference. It was a day of firsts and onlys. It was my first trip to San Francisco and my first run along Fisherman's Wharf, through Golden Gate Park, to the foot of the famed Golden Gate Bridge. The wharf was bustling with predawn delivery trucks and with street merchants slicing fish. The rising sun sliced the lingering fog and softly lit the great bridge.

Later that morning, Steve Benton and I, assistant professor colleagues at Kansas State University, navigated the hilly streets around our hotel until we found our breakfast spot-a simple diner with a few cramped booths and tables. It was a popular spot with AERA attendees. At nearly every table, briefcase-totting academics wore blue blazers with crooked nametags pinned to the lapels and studied conference programs.

Steve and I soon grabbed a small table and waited to meet John Glover. John had been Steve's advisor at the University of Nebraska. Glover and I had never met but Steve's tales portrayed a bullish superhero churning out scholarly books on learning, development, creativity, and animal training; grinding out research articles sometimes containing five or six experiments; exhorting his graduate students to follow his lead and to write at least six pages every day; and scolding administrators who forget a university's true purpose of educating students.

John's entrance was enigmatic. He burst through the door and I was immediately swallowed by his presence. He was a mountain with a mustache - tall, wide, and strong. He strode to our table, gave Steve a warm greeting, and then locked his eyes on mine. He thrust out his powerful right hand, swallowed mine, and then pierced any tension I felt meeting the legendary Glover. "You've been doing great work," he bellowed still clutching my hand, "I'm going to be citing your work on note taking in my educational psychology text." As he let go and stepped around the table to join us, I only then noticed that he was dressed from ankles to shoulders in a canary yellow sweat suit. He was a yellow mountain.

That morning, John graciously invited Steve and me to contribute a chapter to a book he was editing. We spoke tirelessly amid waffles and coffee about research and our passions for educational psychology. We shook hands again when we parted on the glowing, saltaired sidewalk never knowing that this was the only time the first three editors of Educational Psychology Review - the journal that John Glover later founded in 1989would meet.

K. A. Kiewra $(\bowtie)$

University of Nebraska, Lincoln, NE, USA

e-mail: kkiewra1@unl.edu 